\title{
Assessment of surface water resources availability using catchment modelling and the results of tracer studies in the mesoscale Migina Catchment, Rwanda
}

\author{
O. Munyaneza ${ }^{1}$, A. Mukubwa $^{2}$, S. Maskey ${ }^{3}$, S. Uhlenbrook ${ }^{3,4}$, and J. Wenninger ${ }^{3,4}$ \\ ${ }^{1}$ University of Rwanda, School of Engineering, Department of Civil Engineering, P.O. Box 3900, Kigali, Rwanda \\ ${ }^{2}$ Nile Equatorial Lakes Subsidiary Action Program (NELSAP), Department of Water Resources Development, \\ P.O. Box 6759, KN 81 St., KCT 5th Floor, Kigali-Rwanda, Rwanda \\ ${ }^{3}$ UNESCO-IHE Institute for Water Education, Department of Water Science and Engineering, P.O. Box 3015, \\ 2601 DA Delft, the Netherlands \\ ${ }^{4}$ Delft University of Technology, Section of Water Resources, P.O. Box 5048, 2600 GA Delft, the Netherlands
}

Correspondence to: O. Munyaneza (munyoma2000@yahoo.fr)

Received: 21 August 2013 - Published in Hydrol. Earth Syst. Sci. Discuss.: 16 December 2013

Revised: 17 October 2014 - Accepted: 11 November 2014 - Published: 18 December 2014

\begin{abstract}
In the present study, we developed a catchment hydrological model which can be used to inform water resources planning and decision making for better management of the Migina Catchment $\left(257.4 \mathrm{~km}^{2}\right)$. The semidistributed hydrological model HEC-HMS (Hydrologic Engineering Center - the Hydrologic Modelling System) (version 3.5) was used with its soil moisture accounting, unit hydrograph, liner reservoir (for baseflow) and MuskingumCunge (river routing) methods. We used rainfall data from 12 stations and streamflow data from 5 stations, which were collected as part of this study over a period of 2 years (May 2009 and June 2011). The catchment was divided into five subcatchments. The model parameters were calibrated separately for each sub-catchment using the observed streamflow data. Calibration results obtained were found acceptable at four stations with a Nash-Sutcliffe model efficiency index (NS) of 0.65 on daily runoff at the catchment outlet. Due to the lack of sufficient and reliable data for longer periods, a model validation was not undertaken. However, we used results from tracer-based hydrograph separation from a previous study to compare our model results in terms of the runoff components. The model performed reasonably well in simulating the total flow volume, peak flow and timing as well as the portion of direct runoff and baseflow. We observed considerable disparities in the parameters (e.g. groundwater storage) and runoff components across the five sub-catchments,
\end{abstract}

which provided insights into the different hydrological processes on a sub-catchment scale. We conclude that such disparities justify the need to consider catchment subdivisions if such parameters and components of the water cycle are to form the base for decision making in water resources planning in the catchment.

\section{Introduction}

Sustainable water resources management interventions are essential in Rwanda to increase or sustain water resources, especially for the agriculture and livestock sectors (UNEP, 2005). However, water resources assessment on the catchment scale is therefore one of the key activities to provide insight into water available for agricultural purposes (Abdulla et al., 2002; Al-Adamat et al., 2010).

The water resources availability assessment requires detailed insights into hydrological processes. However, studying the complexity of hydrological processes, needed for sustainable catchment management, is basically based on understanding rainfall characteristics and catchment properties (Abushandi, 2011), for which rainfall-runoff modelling studies are useful (Yener et al., 2007). Rainfall-runoff models have been widely used in hydrology over the last century for a number of applications and play an important 
role in optimal planning and management of water resources in catchments (e.g. Pilgrim et al., 1988; O'Loughlin et al., 1996). Pilgrim et al. (1988) and Oyebande (2001) reported that the main challenge associated with successfully applying rainfall-runoff model lies in the lack of monitored data, mainly rainfall spatial distribution over the catchment area, since rainfall is the primary input in any hydrological model. Another potential problem is having no reliable flow data that can lead to the reliable calibration and validation of catchment parameters. In particular, the latter challenge applies to Rwanda, where many catchments are ungauged or even those that are gauged have unreliable information.

In the last 5 years, Rwanda has been moving from centralized to decentralized water resources management, with which related decisions are to be made at catchment level as opposed to administrative levels, as was the case of centralized system. This has been done in line with addressing goal 7 (to ensure environmental sustainability) of the Millennium Development Goals (MDGs) by elaborating Rwanda Vision 2020, EDPRS I (2007-2012) and EDPRS II (20132018). The ultimate goal is to manage water resources in an integrated way and at the lowest possible basin level. Therefore, not only will the findings of this study contribute to enhancing our knowledge base, but they will also contribute to informed decision making in water resources development planning in the Migina Catchment.

A number of research studies have been conducted in this catchment during the last few years (SHER, 2003; Nahayo et al., 2010; van den Berg and Bolt, 2010; Munyaneza et al., 2010, 2012a, b). However, The University of Rwanda, Huye Campus, which lies in the Migina Catchment, supported the idea to build a pilot demonstration site on which models can be built/tested. The result is an integration of water resources development with the university curriculum development and planning processes. The approach applied on the Migina can be used for similar studies in other catchments in the region.

In the present study, the Hydrologic Engineering Center the Hydrologic Modelling System (HEC-HMS) was adopted as a hydrologic modelling tool for assessing the water resources availability in a mesoscale catchment. The model was selected due to its capacity to analyse the spatial variation of runoff generation characteristics, simplicity in setup, limited data requirements and the free availability of the software.

The HEC-HMS model was set up in the mesoscale Migina Catchment $\left(257.4 \mathrm{~km}^{2}\right)$, located in southern Rwanda, to simulate the catchment discharge and to assess spatiotemporal availability of water resources. Computations in HEC-HMS include loss calculations, conversion of extreme rainfall to runoff, baseflow estimation, and routing in reaches and reservoirs (Sardoii et al., 2012).

HEC-HMS has been successfully applied in many catchments worldwide. For example: Christopher and Yung (2001) used HEC-HMS to perform a grid-based hydrologic analysis of a catchment. They compared distributed, semi-distributed and lumped models and reasonable contribution of flood observation and runoff volume. Fleming and Neary (2004) successfully used HEC-HMS as a tool for continuous hydrologic simulation in the Cumberland River basin. Neary et al. (2004) applied the HEC-HMS model to continuous simulation by comparing streamflow simulations using basin-average gauge and basin-average radar estimates. Cunderlik and Simonovic (2005) also used the continuous simulation version of the HEC-HMS model to describe the main hydroclimatic processes in the Ontario River basin. Chu and Steinman (2009) carried out continuous hydrologic simulations by applying HEC-HMS to the Mona Lake watershed in west Michigan. Bouabid and Elalaoui (2010) used HEC-HMS for assessing the impact of climate change on water resources in the Sebou Basin in Morocco. Boyogueno et al. (2012) applied HEC-HMS for the prediction of flow rate in Sanaga Basin in Cameroon.

Before starting this study, we did not find any research which has been conducted in Rwandan catchments using the HEC-HMS model. However, this study used HEC-HMS version 3.5 for testing its applicability in a mesoscale catchment and to inform water resources planning and decision making for better use of Migina Catchment. This work went beyond the standard calibration of the model to the total flow in order to verify estimated values of one runoff components, i.e. baseflow. Baseflow contribution estimates cannot be validated using the standard method (comparison with records). This paper calls for a new approach with which the baseflow results from the rainfall-runoff model were verified using the results of tracer investigations (Munyaneza et al., 2012a).

The main objective of this study is to analyse the spatial variation of the runoff generation characteristics of the Migina Catchment using a semi-distributed hydrological model. The model provides assistance as a tool for water resources planning and decision making processes in this catchment. The model is calibrated using detailed 2 years of rainfall and runoff data collected as part of this study, and tracer-based hydrograph separation results from a previous study (Munyaneza et al., 2012a) are used for the validation of the model in terms of runoff components.

\section{Study area}

The study was carried out in the mesoscale Migina Catchment, which is located in southern Rwanda (Fig. 1). The total area of the Migina Catchment is $243.2 \mathrm{~km}^{2}$. The basin is located in a mountainous area with elevation ranging from $1375 \mathrm{~m}$ a.s.l. at the outlet to $2278 \mathrm{~m}$ a.s.l. at Mount Huye. Table 1 summarizes the main characteristics of the five subcatchments. Migina is the name of the perennial river until it flows into the Akanyaru River, which forms the border between Rwanda and Burundi. The Akanyaru River drains into the Akagera River, which in turn flows into Lake Victoria and later generates the White Nile. 


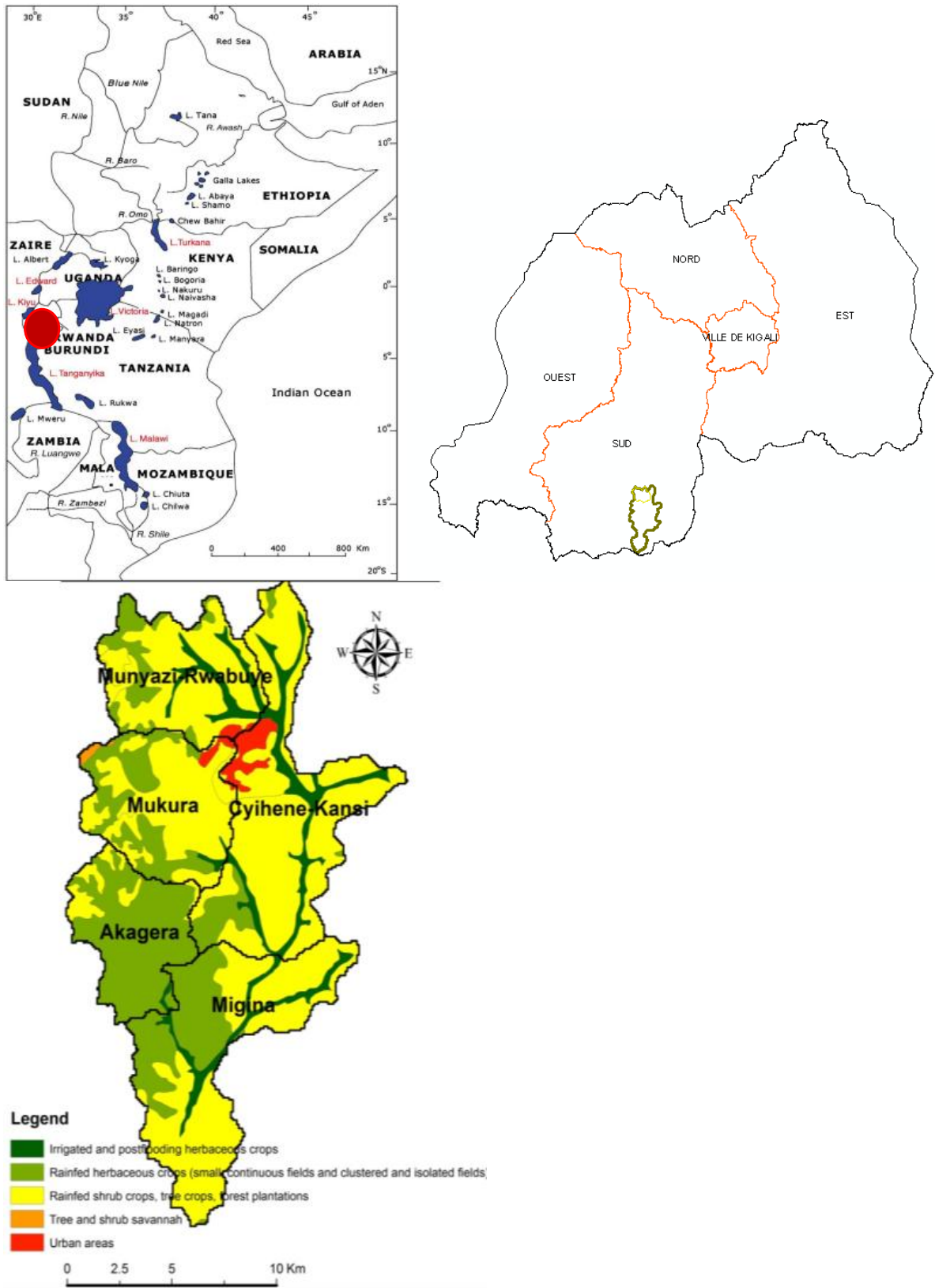

Figure 1. Location, land use and sub-catchments of the Migina Catchment within Rwanda administration map.

The topographic conditions vary from sub-catchment to sub-catchment, and the slopes vary from 5 to $10 \%$ in the upstream and from 1 to $21 \%$ in the downstream part of the basin (average slope of the sub-catchments varies between 2 and $3 \%$ ) (see Table 1 and Nahayo et al., 2010).

The Rwanda National Water Resources Master Plan (RNRA, 2014) has divided the country's watershed into four levels with two main basins of the first order (Congo and Nile). The Migina Catchment is the third-level basin, within catchments which have more or less uniform hydrological characteristics (mostly defined by land use, topography and geology). The surface areas of basins of the third level are typically of the order of at least 10 to possibly some hundreds of $\mathrm{km}^{2}$ (RNRA, 2014), and it is at that level that all water resources interventions shall be planned. In other words, for sustainable water resources planning and management, development and related environmental interventions shall be tailored to the characteristics of a specific catchment like Migina (Fig. 1).

As depicted in Fig. 1, the land cover/land use in the Migina Catchment is dominated by agricultural activities $(91.2 \%)$. Forests occupy $6.5 \%$, grass/lawn areas $0.2 \%$ and 
Table 1. Migina Catchment and sub-catchments characteristics.

\begin{tabular}{|c|c|c|c|c|c|c|c|c|}
\hline \multirow{2}{*}{$\begin{array}{l}\text { Sub-catchment name } \\
\text { (code) }\end{array}$} & \multirow{2}{*}{$\begin{array}{c}\text { Catch. } \\
\text { area } \\
\left(\mathrm{km}^{2}\right)\end{array}$} & \multirow{2}{*}{$\begin{array}{c}\text { Total } \\
\text { rainfall } \\
\left(\mathrm{mm} \mathrm{yr}^{-1}\right)\end{array}$} & \multirow{2}{*}{$\begin{array}{c}\text { Basin } \\
\text { slopes } \\
(\%)\end{array}$} & \multirow{2}{*}{$\begin{array}{c}\text { Imperviousness } \\
(\%)\end{array}$} & \multicolumn{4}{|c|}{ Land use $(\%)$} \\
\hline & & & & & Agriculture & Forests & $\begin{array}{c}\text { Grass/ } \\
\text { lawn }\end{array}$ & $\begin{array}{l}\text { Urban } \\
\text { areas }\end{array}$ \\
\hline Munyazi (W380) & 38.6 & 1453.0 & 15.8 & 3.5 & 90.2 & 8.2 & 0.0 & 1.6 \\
\hline Mukura (W410) & 41.6 & 1665.5 & 19.5 & 2.8 & 84.9 & 11.5 & 1.4 & 2.2 \\
\hline Cyihene-Kansi (W400) & 69.6 & 1456.6 & 12.5 & 6.3 & 89.4 & 5.8 & 0.0 & 4.8 \\
\hline Akagera (W650) & 32.2 & 1507.0 & 20.8 & 8.5 & 87.9 & 12.1 & 0.0 & 0.0 \\
\hline Migina outlet (W640) & 61.1 & 1415.2 & 18.6 & 4.5 & 100.0 & 0.0 & 0.0 & 0.0 \\
\hline
\end{tabular}

urban areas $2.0 \%$ only. This land use distribution indicates that most of the water in the Migina Catchment is used for agricultural purposes (rain-fed or irrigation).The catchment boundaries were delineated from the digital elevation model (DEM) map obtained from the Shuttle Radar Topography Mission (SRTM) through the USGS website ${ }^{1}$ with a resolution of $90 \mathrm{~m}$ using GIS tools, and sub-catchment areas were generated automatically by HEC-GeoHMS 5.0, an extension to ESRI ArcGIS 10.0. The catchment was subdivided into five sub-catchments as shown in Fig. 1. Two sub-catchments are located upstream (Munyazi-Rwabuye $\left(38.6 \mathrm{~km}^{2}\right)$ and Mukura $\left(41.6 \mathrm{~km}^{2}\right)$ ), two in the centre (Akagera $\left(32.2 \mathrm{~km}^{2}\right)$ and Cyihene-Kansi $\left(69.6 \mathrm{~km}^{2}\right)$ ) and one sub-catchment, which also contains the outlet of the whole catchment: Migina $\left(61.1 \mathrm{~km}^{2}\right)$ (see Table 1). The main flow direction in the catchment is from north to south. The main stream is located in the eastern part of the catchment. Therefore, most of the valleys drain from north-west to south-east towards the main stream.

The Migina Catchment has a moderate climate with relatively high rainfall and an annual cycle of two rainy seasons: March to May and September to November (FAO, 2005). The mean annual rainfall in the Migina Catchment is approximately $1200 \mathrm{~mm} \mathrm{yr}^{-1}$, and the mean annual temperature is about $20^{\circ} \mathrm{C}$ (SHER, 2003). The annual average evaporation in the area is estimated to be $917 \mathrm{~mm} \mathrm{yr}^{-1}$ (Nahayo et al., 2010).

\section{Data and methods}

The assessment involved collecting and screening required data, selecting and building the rainfall-runoff model, calibrating the simulated flows for each individual subcatchment, and analysing and interpreting the results.

\subsection{Data}

In order to build the model, the following meteorological and hydrological data were collected: (i) rainfall; (ii) temperature; (iii) solar radiation; (iv) relative humidity and (v) stream

\footnotetext{
${ }^{1}$ http://www.dgadv.com/srtm30/
}

flows. As part of this work, the Migina Catchment was equipped with 12 and 5 with stations rainfall and streamflow instruments, respectively. Rainfall and runoff data were collected over 2 years (May 2009 to June 2011), whereas other meteorological data were obtained from the Center of Geographic Information System (CGIS) station (Butare), which has been operational since February 2006. Rainfall data from only 12 stations were used in this study, given that the rainfall data collected at the CGIS station were not complete. The water levels were measured continuously at five river gauging stations using manual recorders (staff gauges) and pressure transducers (mini-diver; DI501). Rating curves were established using discharge measurements at different periods from May 2009 to June 2011 (Eq. 1). The recorded water levels were converted into discharge values using rating curves $\left(r^{2}=0.88, n=25\right.$ at Rwabuye station; $r^{2}=0.96$, $n=25$ at Akagera station; $r^{2}=0.94, n=24$ at Kansi station; $r^{2}=0.80, n=28$ at Mukura station; and $r^{2}=0.97, n=18$ at Migina station); note that $n$ represents the number of discharge measurements).

The applied rating curve is presented, for instance, by De Laat and Savenije (2002) and De Laat (2006):

$Q=a\left(H-H_{0}\right)^{b}$,

where $Q$ is the discharge in $\mathrm{m}^{3} \mathrm{~s}^{-1}, H$ is the water level in the river in $\mathrm{m}, H_{0}$ is the gauge reading at zero level, and $a$ and $b$ are constants. The value of $H_{0}$ is determined by trial and error while the values $a$ and $b$ are found by a plot on logarithmic paper and by the fit of a straight line or by a least square fit using the measured data.

Daily temperature and solar radiation data used to compute evaporation were collected at the CGIS-Meteo station using the Priestley-Taylor method. Considering the small size of the Migina Catchment (about $260 \mathrm{~km}^{2}$ ), we did not expect the average radiation and temperature to vary in a way that could considerably affect evaporation values. Rainfall data at 12 stations scattered in the study area were analysed using the Thiessen polygon method (May 2009 to June 2011) for the interpolation of the daily rainfall average and using the mass curve method for quality control.

All mass curves of rainfall in the Migina Catchment have similar behaviour except for Rango station, which shows sig- 
nificantly higher rainfall than other stations due to unknown reasons. The station was still used in the analysis as there was no obvious reason identified to reject it. Other climatic data including temperature, relative humidity and solar radiation were used as collected at the CGIS station, Butare, in the absence of similar nearby stations for comparison. Though the model used (HEC-HMS) does not allow entering soil texture/properties during the model set-up, the expected difference in response of different soils is addressed partially during calibration through the adjustment of infiltration rates in different sub-catchments.

Based on the findings of the data quality analysis, it was decided to limit the simulation work to the period between 1 August 2009 and 31 July 2010, with the condition of covering the entire calendar year. However, owing to a lack of reliable long-time observed flow data, the model validation could not be done in this study and all available data were used for model calibration. The model was validated using tracer-based hydrograph separation results to compare the model results in terms of the runoff components (Hoeg et al., 2000; Wenninger et al., 2008; Munyaneza et al., 2012a).

\subsection{Methods}

Two main tools were used in this study: the HEC-HMS 3.5 for the rainfall-runoff simulation and HEC-GeoHMS 5.0 for catchment delineation.

\section{Hydrological model (HEC-HMS 3.5)}

The HEC-HMS is a semi-distributed hydrological model, designed to simulate the rainfall-runoff processes for catchment systems (USACE, 2008; Scharffenberg and Fleming, 2010). Its design allows its applicability in a wide range of geographic areas for solving diverse problems including large river basin water supply and flood hydrology and small urban or natural catchment runoff (Merwade, 2007).

The latest available version HEC-HMS 3.5 was used in this study. Given rainfall values as input data, the HECHMS calculates outflow from the sub-catchment element by subtracting evaporation, calculating surface/direct runoff and adding baseflow. A full description of all components in HEC-HMS can be found in the user manual (USACE-HEC, 2010).

The Migina Catchment was divided into five subcatchments for computing evaporation and percolation, baseflow, and transform and routing computation methods, and parameters were defined to convert rainfall into runoff.

The HEC-GeoHMS Version 5.0 was used with ArcGIS 10.0 to derive land use and the river network of the catchment and to delineate sub-catchments of the Migina Catchment. With GeoHMS, the project area was automatically delineated and its basin characteristics were generated (area, reach length, river slopes, etc.). In addition, the HEC-GeoHMS created background map files and basin

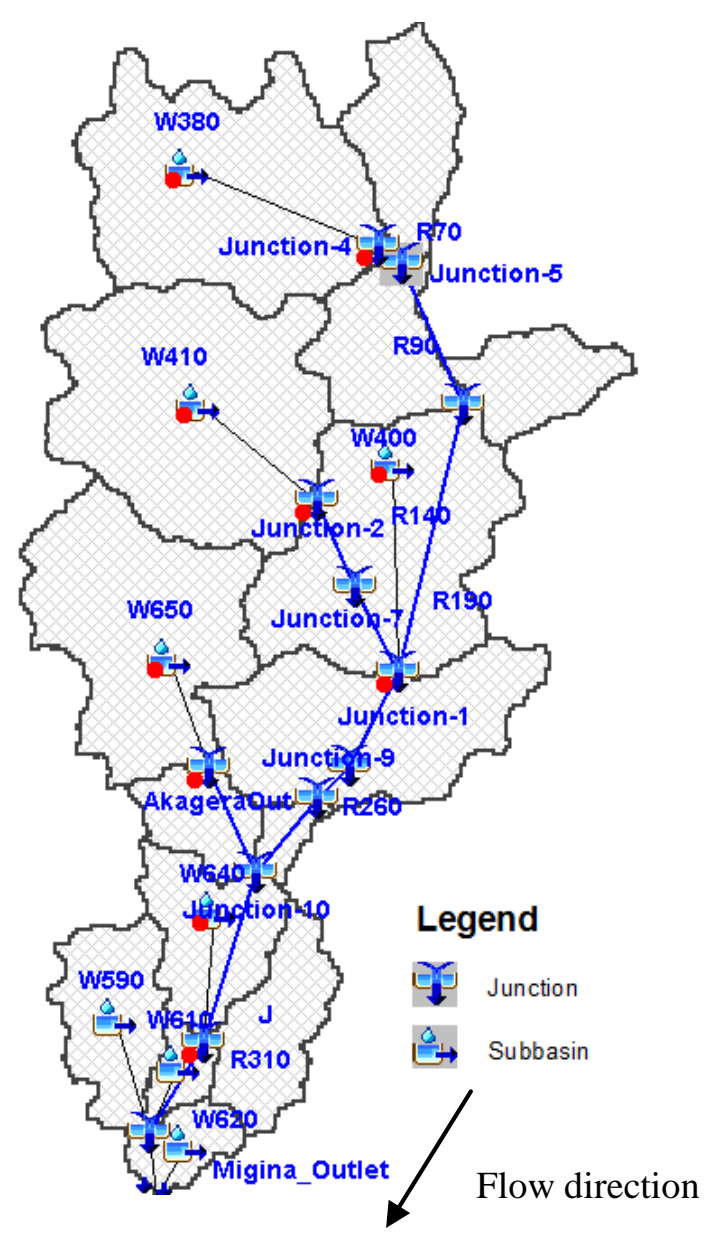

Figure 2. Migina Catchment model set-up in HEC-HMS.

model files, which were later used by HEC-HMS to develop a hydrologic model. The sub-catchments delineation resulted in sub-catchments: Munyazi-Rwabuye (W380), Mukura (W410), Cyihene-Kansi (W400), Akagera (W650) and Migina (W640) (see Fig. 2).

\subsection{Computation methods}

To compute the different water balance components, the following computation methods, as referred to in the HEC-HMS literature, were applied to the sub-catchments (e.g. Yawson et al., 2005) and reaches.

i. The loss method (name as per HEC terminology as a real loss does not exist in the hydrological cycle) allows computing basin surface runoff, groundwater flow and actual evaporation, as well as deep percolation out of the basin. The soil moisture accounting (SMA) was selected as the appropriate approach to convert rainfall hyetograph into excess rainfall. In conjunction with the SMA, the canopy and surface losses (interception) were 
Table 2. Calibrated parameter values for each sub-catchment.

\begin{tabular}{|c|c|c|c|c|c|c|}
\hline Method & Parameter & $\begin{array}{l}\text { Munyazi } \\
\text { (W380) }\end{array}$ & $\begin{array}{l}\text { Mukura } \\
\text { (W410) }\end{array}$ & $\begin{array}{l}\text { Cyihene- } \\
\text { Kansi } \\
\text { (W400) }\end{array}$ & $\begin{array}{l}\text { Akagera } \\
\text { (W650) }\end{array}$ & $\begin{array}{l}\text { Migina } \\
\text { outlet } \\
\text { (W640) }\end{array}$ \\
\hline Canopy & Max storage (mm) & 3 & 3 & 2 & 1 & 2 \\
\hline Surface & Max storage (mm) & 5 & 20 & 3 & 2 & 3 \\
\hline \multirow[t]{10}{*}{ Loss } & Initial wet soil storage (\%) & 35 & 35 & 35 & 35 & 55 \\
\hline & Groundwater $1(\%)$ & 65 & 65 & 75 & 75 & 81.4 \\
\hline & Max infiltration $\left(\mathrm{mm} \mathrm{h}^{-1}\right)$ & 10 & 7.5 & 5.5 & 7.5 & 12 \\
\hline & Impervious $(\%)$ & 3.5 & 2.75 & 6.3 & 8.5 & 4.5 \\
\hline & Soil storage (mm) & 48 & 30 & 50 & 40 & 13.8 \\
\hline & Tension storage (mm) & 15 & 5 & 5 & 4 & 5 \\
\hline & Soil percolation $\left(\mathrm{mm} \mathrm{h}^{-1}\right)$ & 4 & 2 & 0.8 & 1.75 & 1.97 \\
\hline & GW 1 storage $(\mathrm{mm})$ & 237.0 & 50.0 & 150.0 & 100.0 & 303.6 \\
\hline & GW 1 percolation $\left(\mathrm{mm} \mathrm{h}^{-1}\right)$ & 2 & 3.6 & 0.5 & 1.3 & 8.159 \\
\hline & GW 1 coefficient $(\mathrm{h})$ & 4320 & 1296 & 1440 & 1014 & 1014 \\
\hline Transform & Lag time [Min] & 120 & 30 & 60 & 45 & 45 \\
\hline \multirow[t]{2}{*}{ Baseflow } & GW 1 initial $\left(\mathrm{m}^{3} \mathrm{~s}^{-1}\right)$ & 0.004 & 0.021 & 0.782 & 0.204 & 0.373 \\
\hline & GW 1 coefficient $(h)$ & 6480 & 3240 & 3746 & 3240 & 6480 \\
\hline
\end{tabular}

also considered and computed using simple canopy and simple surface methods (HEC, 2011).

ii. Transform method (runoff generation module) allows us to specify how to convert excess rainfall into direct runoff. This method employs the Soil Conservation Service (SCS) technique (dimensionless unit hydrograph). The method requires only one parameter as input for each sub-catchment: lag time $\left(T_{\text {lag }}\right)$ between rainfall and runoff in the sub-catchment (Eq. 2). The SCS developed a relationship between the time of concentration $\left(T_{\mathrm{c}}\right)$ and the lag time $\left(T_{\text {lag }}\right)$. Lag time represents the duration of time between the centroid of rainfall mass and the peak flow of the resulting hydrograph. HEC-HMS includes an implementation of Snyder's unit hydrograph (UH). In his work, Snyder (1938) selected the lag, peak flow and total time base as the critical characteristics of a UH. He defined a standard UH as one whose rainfall duration $\left(\frac{\Delta t}{2}\right)$ is related to the basin lag $\left(T_{p}\right)$ as shown in Eq. (3).

$T_{\text {lag }}=0.6 T_{\mathrm{c}}$

$T_{p}=\frac{\Delta t}{2}+T_{\text {lag }}$,

where $T_{\text {lag }}$ is the lag time [min], $T_{\mathrm{c}}$ is the time of concentration [min], $T_{p}$ is the basin lag [min] and $\frac{\Delta t}{2}$ is the duration of excess rainfall [min].

iii. Baseflow method performs subsurface flow calculation. The linear reservoir baseflow method was considered due to its simplicity and suitability for the SMA approach. iv. The Muskingum-Cunge method, which is the routing technique used for the reaches, was selected in this model because of its numerical stability. The reach characteristics used were mainly produced by the HECGeoHMS (length and slope), and others borrowed from the previous publications carried out in the same catchment such as in SHER (2003), Van den Berg and Bolt (2010) and Munyaneza et al. (2010, 2011, 2012a, b) were also used.

\subsection{Basin model set-up and simulations}

\subsubsection{Basin model}

In the present study, the basin model was created using the HEC-GeoHMS and then imported into the HEC-HMS with all its hydrologic elements: 5 sub-catchments, 10 junctions, 11 reaches and a sink used to represent the outlet of a basin (node with inflow and without outflow) (Fig. 2). Where applicable, the junction elements were assigned to observed flow data, for use in comparison with simulated flows during the calibration process. In the model parameterization process, each hydrologic unit was supplied with initial conditions and parameter values based on the requirements of the different computation methods as discussed in Sect. 3.3. Initial parameter values were selected based on previous (published) works where available; otherwise default values from the manual were applied. Table 2 shows the five model routines: canopy, surfaces, loss, transform and baseflow; the type of parameters used for each method; and values attributed to each parameter in the modelling process (calibrated). 


\subsubsection{Meteorological model}

The meteorological model was created after having created the basin model. The meteorological model in HEC-HMS includes rainfall and actual evaporation methods to be used in the simulations (Arbind et al., 2010).

In this study, the rainfall and evaporation data which are essential to simulate catchment processes were stored in the meteorological model. Twelve rain gauges and the inverse distance method for rainfall computation were used in this model. The Priestley-Taylor method was used for computing total evaporation using temperature and radiation data. The current HEC-HMS 3.5 version allows actual evaporation computation using temperature and the radiation-based method in combination with the soil moisture accounting (SMA) model.

\subsection{Calibration methods}

In the present study, a combination of manual and automated calibration techniques was used. Automated calibration, known as "trial optimization" in HEC-HMS, was used to obtain optimum parameter values that give the best fit between observed and simulated flow volume values (Ruelland et al., 2008).

Given the availability of flow at the outlet of different sub-catchments, calibration has been done catchment-wise, starting from the farthermost upstream catchments (Munyazi, Mukura and Akagera), since what happens upstream affects the results downstream.

\subsection{Model performance evaluation}

The calibrated model performance was evaluated using the Nash-Sutcliffe model efficiency (NS) (Nash and Sutcliffe, 1970; Miao et al., 2013). The NS is used to assess the agreement between observations and simulations. Mathematically, it is expressed as

$$
\mathrm{NS}=1-\frac{\sum_{t=1}^{T}\left(Q_{0}^{t}-Q_{\mathrm{m}}^{t}\right)^{2}}{\sum_{t=1}^{T}\left(Q_{0}^{t}-\overline{Q_{0}}\right)^{2}},
$$

where $Q_{0}^{t}$ is observed discharge at time $t, \overline{Q_{0}}$ is average observed discharge and $Q_{\mathrm{m}}$ is modelled discharge at time $t$; all $Q$ variables have the unit runoff volume per time step (e.g. $\mathrm{m}^{3} \mathrm{~s}^{-1}$ ).

Nash-Sutcliffe efficiencies can range from $-\infty$ to 1 . An efficiency of $1(\mathrm{NS}=1)$ corresponds to a perfect match between the modelled and observed time series, whereas an efficiency of $0(\mathrm{NS}=0)$ indicates that the model predictions are as accurate as the mean of the observed data. If the efficiency is less than $0(\mathrm{NS}<0)$, the observed mean is a better predictor than the model. More detailed information on NS can be found in Legates (1999), McCuen et al. (2006), Schaefli and Gupta (2007) and Kashid et al. (2010).

\subsection{Tracer techniques for model validating}

Hydrograph separations to separate the total discharge during floods into two or more components, based on the mass balances for tracer and water fluxes, were applied in Munyaneza et al. (2012a). They applied the two- and three-component hydrograph separation models in two sub-catchments of Cyihene-Kansi and Migina using environmental isotopes (oxygen-18 $\left({ }^{18} \mathrm{O}\right)$ and deuterium $\left.\left({ }^{2} \mathrm{H}\right)\right)$ and hydrochemical tracers (dissolved silica $\left(\mathrm{SiO}_{2}\right)$ and chloride $\left(\mathrm{Cl}^{-}\right)$). The investigated events took place from the 1 to 2 May 2010 at the outlet of the Cyihene-Kansi sub-catchment and from 29 April to 6 May 2011 at the outlet of the Migina Catchment. The results show that subsurface runoff dominates the total discharge even during flood events. More than $80 \%$ of the discharge was generated by subsurface runoff for two investigated events. This dominance of subsurface contributions is also in line with the observed low runoff coefficient values (16.7 and $44.5 \%)$ for both events. Hence, groundwater recharge mainly during the wet seasons leads to a perennial river system in the Migina Catchment.

\section{Results and discussion}

\subsection{Calibration results}

After running initial parameters over the simulation period and plotting the results against the observed flows, the first run did not yield acceptable results and the initial parameters were subjected to calibration. The model is calibrated using 2 years of rainfall and runoff data collected as part of this study (August 2009 to June 2011). However, owing to the lack of reliable long-term flow observations, a classical model validation (e.g. split-sample test) could not be done in this study and all available data were used for the model calibration. The final calibrated parameters for each sub-catchment are presented in Table 2. The data in Rwanda are often challenging where many catchments are ungauged and even the gauged catchments have unreliable data sets. Additionally, the suitability of the model was checked using the results of tracer investigations.

Table 2 shows that the calibrated parameter values obtained varied from sub-catchment to sub-catchment. The differences observed between the parameter values across the different sub-catchments were relatively small, except in some few cases where differences were considerable. The parameters with considerable differences include the following: (i) maximum infiltration, (ii) maximum initial wet soil storage (iii) GW 1 storage, (iv) lag time and (v) GW 1 coefficient. All four formed sensitive parameters for the catchment. The initial values for soil moisture were collected from the Mukura sub-catchment at Kadahokwa Marshland. Be- 
Table 3. Residual values for each discharge computation point with corresponding NS. The simulation period is 12 months (1 August 2009 to 31 July 2010). The positive sign (+) means that the model overestimated the flows, while the negative sign $(-)$ means that the model underestimated the flows.

\begin{tabular}{llrrrr}
\hline $\begin{array}{l}\text { Sub-catchment } \\
\text { name (code) }\end{array}$ & $\begin{array}{l}\text { Station } \\
\text { name }\end{array}$ & $\begin{array}{r}\text { Total } \\
\text { observed } \\
\left(\mathrm{mm} \mathrm{yr}^{-1}\right)^{*}\end{array}$ & $\begin{array}{r}\text { Total } \\
\text { simulated }_{\left(\mathrm{mm} \mathrm{yr}^{-1}\right)^{*}}\end{array}$ & $\begin{array}{r}\text { Residual in } \\
\% \text { of total } \\
\text { observed } Q\end{array}$ & NS [-] \\
\hline Munyazi (W380) & Rwabuye & 64.98 & 67.11 & 3.28 & 0.38 \\
Mukura (W410) & Mukura & 60.32 & 59.20 & -1.86 & 0.62 \\
Cyihene (W400) & Kansi & 366.93 & 382.63 & 4.28 & 0.51 \\
Akagera (W650) & Akagera & 296.89 & 322.35 & 8.58 & 0.61 \\
Migina outlet (W640) & Migina & 324.71 & 318.98 & -1.76 & 0.65 \\
\hline
\end{tabular}

* The discharges are expressed in millimetres per entire simulation time.

cause the soil parameters were collected in only one subcatchment, we could not verify these parameter values for other sub-catchments but had to rely on calibration.

Although correlation between infiltration rate and subcatchment slopes was not strong $(r=0.33)$, the higher infiltration rate value is observed in the most lowland areas of the Migina sub-catchment, where the slopes are gentle and herbaceous and shrub crops dominate the land cover (almost $100 \%$ ) (see Table 1).

Groundwater storage values were higher in subcatchments that, due to their physiographic settings, have larger valley floors (Cyihene-Kansi and Migina). Subcatchments of Mukura and Akagera showed small storage, mainly due to their high surface runoff induced by very steep slopes. This also translates into their low contribution of the baseflow to the total flow.

The difference observed in the groundwater coefficients across the basin shows the varying behaviour of the different sub-catchments in transforming groundwater into baseflow. The groundwater coefficient represents the time lag applied to the linear reservoir for transforming water in groundwater storage into lateral flow, which generate baseflow in the river. The correlation analysis showed that a stronger correlation exists between the groundwater coefficient and the groundwater storage capacity $(r=0.94)$ compared with the correlation between groundwater storage and size of the subcatchment $(r=0.39)$.

With respect to lag time, it was noticed that despite a weak correlation between lag time and basin mean slope, the subcatchment with very steep slopes (Mukura) showed a faster response than those with gentle slopes (Munyazi) (see Tables 1 and 2).

\subsubsection{Flow results}

Generally, the model predicted the flow volumes well, though difficulties in matching simulated and observed daily flows were observed.

Particular attention was given mainly to control points that collect water from more than one sub-catchment (Cyihene-
Kansi and Migina outlets). During the calibration process, we tried to minimize the absolute values of the residuals of the observed flow volumes. In addition, the NS was used to better evaluate the performance of the calibrated model. Table 3 summarizes the obtained NS coefficients and total flow residual values for each discharge computation point in the basin.

Table 3 shows that the model performed reasonably well in simulating total flow volumes (Roy et al., 2013). The residues as a percentage of the total observed range between -1.86 and $8.58 \%$ of observed flow. Results indicated by NS coefficients also depicted reasonable model performance in most cases (NS >0.5), with the exception of Munyazi subcatchment $(\mathrm{NS}=0.38)$. This low value of NS observed at Munyazi sub-catchment could not be fully explained and more research should be done. Furthermore, the model simulated the baseflow well, while at the same time reproducing the observed peaks in terms of timing and quantity (Fig. 3). For instance, the model was able to reproduce the peak recorded at all stations on 2 May 2010 as shown in Fig. 3. Similar results were obtained by Munyaneza et al. (2012a), who investigated the peak discharge in the same catchment and observed the same peaks at the same time as in the current study (see Sect. 4.3.1).

In individual sub-catchments, the model performed relatively well in sub-catchments Akagera, Mukura and Migina (the outlet), with NS coefficients of $0.61,0.62$ and 0.65 , respectively.

Moreover, baseflows were also well simulated in most cases, with the exception of that at the Cyihene-Kansi (Fig. 3a) and Migina outlet (Fig. 3b), where the model, respectively, overestimated and underestimated the baseflow in dry seasons (June-July 2010). The main reason our model simulates high and low recession of baseflow at CyiheneKansi and Migina outlets after a storm event may be linked to the inflexibility of the model structure. The results could have been improved by using a flexible model structure, e.g. FLEX-Topo (Fenicia et al., 2008a, b, 2010; Savenije, 2010; Gao et al., 2014). Savenije (2010) demonstrated that 

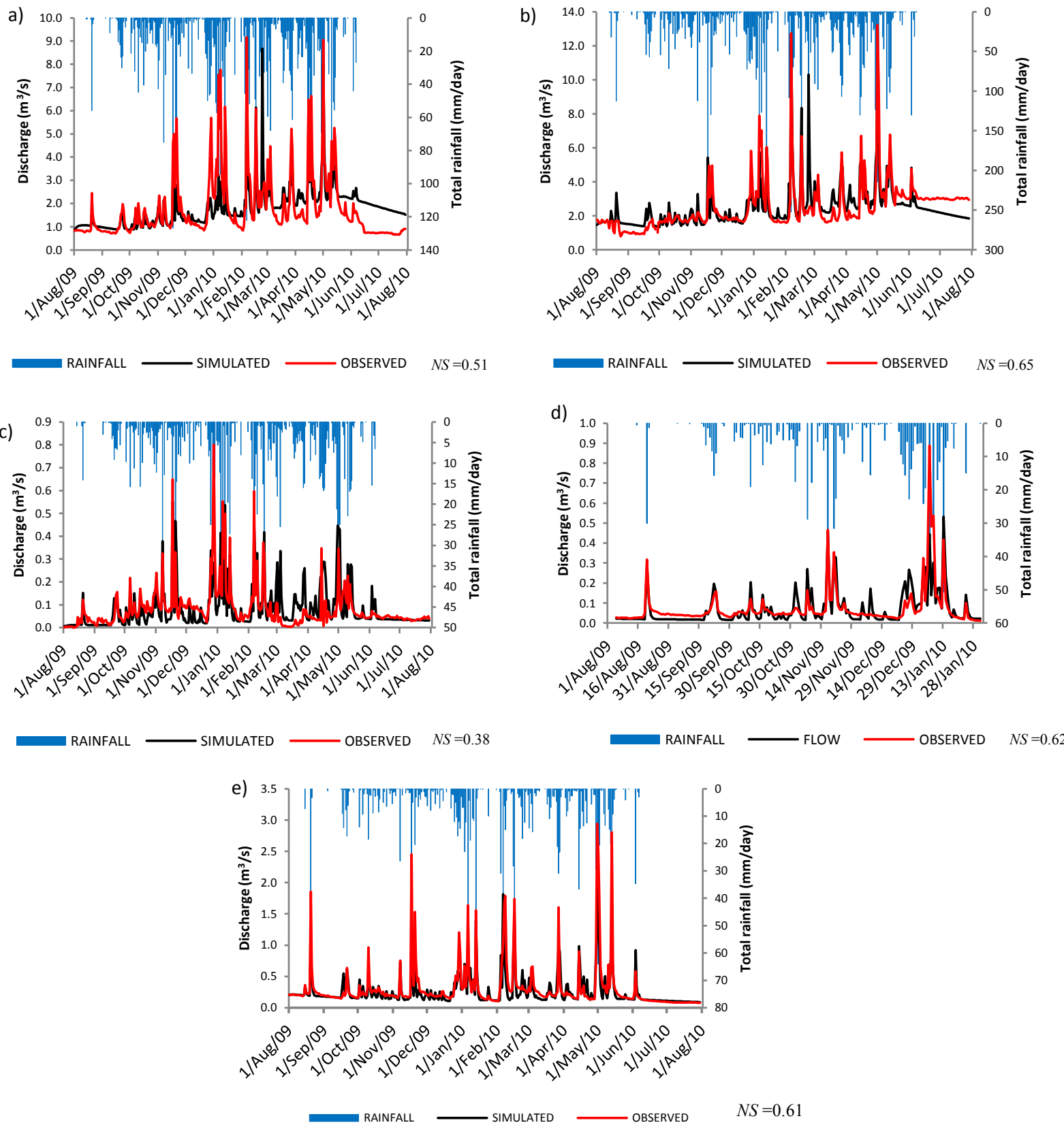

Figure 3. The simulated and observed hydrographs at (a) Cyihene-Kansi, (b) Migina outlet, (c) Munyazi, (d) Mukura and (e) Akagera sub-catchments.

the FLEX-Topo model allows the groundwater timescales to be lumped and determined by manual calibration on the recession curve. A more flexible model structure would, in particular, allow us to design in particular the runoff generation module (different runoff response functions) based on the process understanding obtained and the physiographic characteristics and dominant landscape elements such as riparian zones, hillslopes and hilltops.

\subsubsection{Simulated water budget components}

With one of the main objectives of water resources assessment in mind (determination of water availability at local sub-catchment level), the catchment water budget components from the model results were analysed. The components are the total rainfall, actual evaporation and percolation, direct runoff, baseflow, and total flow. The quantities are presented in Table 4 and represent the total volume over the simulation period of 12 months (1 August 2009 to 31 July 2010). 
Table 4. Budget component quantities for all sub-catchments in the simulated period of 12 months.

\begin{tabular}{|c|c|c|c|c|c|c|c|c|}
\hline $\begin{array}{l}\text { Sub-catchment name } \\
\text { (code) }\end{array}$ & $\begin{array}{c}\text { Total } \\
\text { rainfall } \\
\left(\mathrm{mm} \mathrm{yr}^{-1}\right)\end{array}$ & $\begin{array}{l}\text { Evaporation } \\
\text { and deep } \\
\text { percolation } \\
\left(\mathrm{mm} \mathrm{yr}^{-1}\right)\end{array}$ & $\begin{array}{r}\text { Direct } \\
\text { runoff } \\
\left(\mathrm{mm} \mathrm{yr}^{-1}\right)\end{array}$ & $\begin{array}{r}\text { Base } \\
\text { flow } \\
\left(\mathrm{mm} \mathrm{yr}^{-1}\right)\end{array}$ & $\begin{array}{r}\text { Total } \\
\text { flow } \\
\left(\mathrm{mm} \mathrm{yr}^{-1}\right)\end{array}$ & $\begin{array}{l}\text { Base } \\
\text { flow in } \\
\% \text { of the } \\
\text { total } \\
\text { flow }\end{array}$ & $\begin{array}{l}\text { Direct } \\
\text { flow in } \\
\% \text { of the } \\
\text { total } \\
\text { flow }\end{array}$ & $\begin{array}{c}\text { Correlation } \\
\text { rainfall- } \\
\text { runoff }(-)\end{array}$ \\
\hline Munyazi (W380) & 1453.0 & 1408.1 & 44.9 & 19.7 & 64.6 & 30.4 & 69.5 & 0.94 \\
\hline Mukura (W410) & 1665.5 & 1622.5 & 43.0 & 16.2 & 59.2 & 27.4 & 72.6 & 0.96 \\
\hline Cyihene-Kansi (W400) & 1456.6 & 1309.7 & 146.9 & 267.6 & 414.4 & 64.6 & 35.4 & 0.73 \\
\hline Akagera (W650) & 1507.0 & 1382.1 & 125.0 & 127.5 & 252.5 & 50.5 & 49.5 & 0.97 \\
\hline Migina outlet (W640) & 1415.2 & 1353.8 & 61.5 & 138.1 & 199.6 & 69.2 & 30.8 & 0.96 \\
\hline
\end{tabular}

Table 4 shows that contributions of direct runoff and baseflows vary from sub-catchment to sub-catchment, despite the small size and closeness of the sub-catchments. Table 4 shows that the outflows for Mukura and Munyazi subcatchments depend highly on direct flow, whereas baseflow contribution was calculated as only 27.4 and $30.4 \%$ of total flow, respectively. The observed dominance of high direct runoff in both sub-catchments may be attributed to the urbanization observed in the catchment areas such as Ngoma, Matyazo and Rwabuye towns (Fig. 1 and Table 1), resulting in relatively large areas of mainly impervious surfaces for rural catchments $(2.8 \%$ of the total catchment areas for Mukura and $3.5 \%$ for Munyazi of the total catchment areas). Opposite results were observed at Cyihene-Kansi and Migina outlet sub-catchments, where the baseflow contributes 64.6 and $69.2 \%$ of total outflow, respectively (see Table 4 and Fig. 4).

In the absence of enough data to validate the model, an attempt was made to compare outputs of the present study with those obtained using techniques other than computational modelling. Two rainfall events were investigated during the rainy season in 2010 and 2011, using flow data collected at Kansi and Migina flow stations. The results showed that the direct runoff component did not exceed 33.7 and $28.7 \%$ of the total event runoff, respectively. The model estimations of 35 and $31 \%$, respectively, are close to the values obtained by tracer methods (Fig. 4). These values are the percentage values for exactly these two events and not for the longer simulation period. We did not expect the average radiation and temperature to vary in a way that could considerably affect evaporation values, which is why we used radiation and air temperature values from one weather station (CGIS) across the entire basin, as this was the only one in the basin.

Note that in the HEC-HMS output the runoff components are referred to as direct runoff and baseflow. In the tracerbased analysis (Munyaneza et al., 2012a), the runoff components are referred to as subsurface runoff, later flows, etc. Here, for comparing the two results, we call them direct runoff and baseflow (as in HEC-HMS). Both the HEC-HMS and the tracer method show the dominance of baseflow in the Cyihene-Kansi and Migina catchments (Fig. 4). These

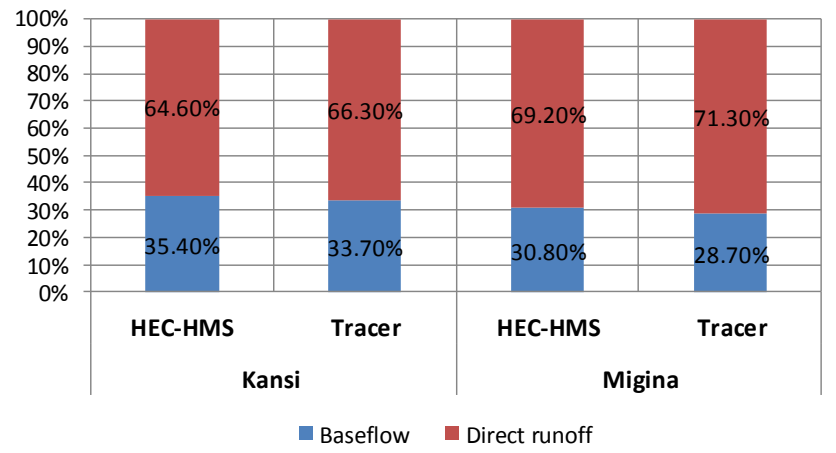

Figure 4. Comparison of flow component results using HEC-HMS model (current study) and hydrochemical tracer method (obtained from Munyaneza et al., 2012a) for two investigated events in the rainy season in 2010 and 2011, using flow data collected at Kansi and Migina river gauging stations.

results are supported by Mul et al. (2008), who conducted a similar study in a semi-arid area, using hydrochemical tracers for hydrograph separation and found that over $95 \%$ of the discharge could be attributed to baseflow during smaller events. This was due to more groundwater contributions to those two downstream sub-catchments in contrast to the upstream sub-catchments.

In addition, the convergence of modelling and tracer techniques shows that tracer data can serve as multi-response data to assess and validate a model, which was also concluded by Uhlenbrook and Leibundgut (2002) and Uhlenbrook et al. (1999). Hence, the model works effectively from a process point of view and, therefore, seems useful for water resources planning purposes in the Migina Catchment. The high contributions of baseflow to total flow translate into high reliability/security of water resources even during dry seasons, hence explaining the predominance of agricultural activities $(91.2 \%)$ in the two sub-catchments (Cyihene-Kansi and Migina), as also found by Munyaneza et al. (2011). This high contribution of baseflow to total flow also confirms the perennial river system observed in the Migina Catchment 
during the study period, which is also supported by Munyaneza et al. (2012a).

Looking at the other components of the basin, for the Akagera sub-catchment $\left(32.15 \mathrm{~km}^{2}\right)$, the baseflow and direct flow contribute about equal amounts to the subcatchment outflow (50.5 and $49.5 \%$, respectively). Compared to other sub-catchments with almost the same size (Munyazi $\left(38.61 \mathrm{~km}^{2}\right.$ ) and Mukura $\left(41.65 \mathrm{~km}^{2}\right)$, Akagera $\left(32.15 \mathrm{~km}^{2}\right)$ ) has a considerably high direct runoff (three times the direct runoff of the other two), mainly attributed to the steep slopes $(20.8 \%)$ and to the high proportion of impervious $(8.5 \%)$ areas in this sub-catchment (see Table 1$)$. However, nothing fully explains the higher baseflow contribution to the total runoff compared with Munyazi and Mukura sub-catchments, except that Cyihene-Kansi and Migina subcatchments receive more groundwater contributions as they are located downstream and all the three sub-catchments (including Akagera) present different hydrological elements (e.g. topography, shape of river channel). We have observed wider valley floods in the downstream part of the catchment and more groundwater contributions in these parts/subcatchments compared to upstream catchments with narrower valley floors and less shallow groundwater storage.

The Cyihene-Kansi sub-catchment $\left(69.63 \mathrm{~km}^{2}\right)$ yields a lot of water compared with the other four sub-catchments. Its high outflow of $414.4 \mathrm{~mm}$ over the simulation period is explained by its high amount of baseflow $(267.6 \mathrm{~mm})$ and higher direct flows $(146.9 \mathrm{~mm})$, resulting most probably from its size being larger than other sub-catchments (Table 1).

In general, the Akagera sub-catchment simulations gave better results - with a high correlation between rainfall and runoff ( $r=0.97$ ) - than the other four sub-catchments (Munyazi, Cyihene-Kansi, Mukura and Migina) (see Table 4). The better result in this sub-catchment may be partly attributed to the Akagera river channel being rectangular in shape, which favours more accurate discharge measurements compared with other rivers in the catchment. The other reason could be that the daily time step used is less suitable for small, steep catchments.

\section{Concluding remarks}

In this study, the model HEC-HMS version 3.5 hydrologic modelling software was applied to the Migina mesoscale catchment, and the model parameters for actual evaporation (soil moisture accounting method) and baseflow (linear reservoir) were calibrated using the observed stream flows. The model performed reasonably well over the calibration period by reproducing the observed flow volumes and simulating the observed peaks in terms of timing and quantity.

The HEC-HMS model was applied to five sub-catchments and the model results were compared with tracer results in two sub-catchments (Cyihene-Kansi and Migina); however, the model was not validated in a classical way due to the lack of reliable data (cf. Du et al., 2007) but checked for its suitability using the results of tracer investigations. This is not a classical model validation (like a split sample test as recommended by Klemes, 1986); however, it provided further insights into the model behaviour and the model performance. Based on the performance of the HEC-HMS model and the tracer method comparison, the present study concluded that the framework works effectively in the mesoscale Migina Catchment but needs to be flexible in its structure for simulating the recession baseflow. The conclusion was that flexible models should probably work better in mesoscale catchments like Migina than models which are not flexible (having fixed applications). This was supported by Fenicia et al. (2011), who proposed flexible models because they allow the hydrologist to hypothesize, build and test different model structures using combinations of generic components. They said that flexible models are particularly useful for conceptual modelling on the catchment scale, where limitations in process understanding and data availability remain major research and operational challenges.

The simulation results gave an indication of zones of high surface runoff and of recharge-/baseflow-generating areas. Those zones present potential areas where catchment protection interventions can be implemented. For example, interventions leading to the protection of the water sources can be implemented in the zones of recharge where infiltration, recharge and temporary groundwater storage are higher. Areas of higher direct runoff, mainly due to the slopes, may also be suitable for interventions leading to the reduction of slopes by terracing and hence increasing infiltration and subsequent recharge.

Moreover, at the mesoscale catchment level, considerable disparities in the parameters and hydrological processes exist. Lumping the entire Migina Catchment would lead to missing important aspects of some of the sub-catchments and, subsequently, potentially misinforming the planning and decision making processes. Depending on the purpose of the assessment and the intended use of the information to be generated, individual units on an appropriate scale may require particular attention even in very small catchments.

Continuous quality assurance and the control of hydrological and weather data sets recorded at different stations in the entire catchment is of great importance for the future.

Acknowledgements. The authors thank the Government of the Netherlands for supporting the Nuffic/NPT under the Water Resources and Environmental Management Project at the University of Rwanda (UR). We also want to thank also the UNESCO-IHE (Delft, the Netherlands) and UR (Huye Campus, Rwanda) for the financial support received. The contribution of H. W. van den Berg and R. H. Bolt (former MSc students at VU University of Amsterdam, the Netherlands) during instrumental field set-up is gratefully acknowledged.

Edited by: N. Ursino 


\section{References}

Abdulla, F. A., Amayreh, J. A., and Hossain, A. H.: Single event watershed model for simulating runoff hydrograph in desert regions, Water Resour. Manage., 16, 221-238, 2002.

Abushandi, E. H.: Rainfall-Runoff Modeling in Arid Areas, PhD Thesis, Faculty for Geosciences, Geotechnique and Mining of the Technische Universität Bergakademie Freiberg, Freiberg, Germany, 2011.

Al-Adamat, R., Diabat, A., and Shatnawi, G.: Combining GIS with multicriteria decision making for silting water harvesting ponds in Northern Jordan, J. Arid Environ., 74, 1471-1477, 2010.

Arbind, K. V., Madan, K. J., and Rajesh, K. M.: Evaluation of HECHMS and WEPP for simulating watershed runoff using remote sensing and geographical information system, Paddy Water Environ., 8, 131-144, doi:10.1007/s10333-009-0192-8, 2010.

Bouabid, R. and Elalaoui, C. A.: Impact of climate change on water resources in Morocco: The case of Sebou Basin, Séminaires Méditerranéens, 9, 57-62, 2010.

Boyogueno, S. H., Mbessa, M., and Tatietse, T. T.: Prediction of Flow-Rate of Sanaga Basin in Cameroon Using HEC-HMS Hydrological System: Application to the Djerem Sub-Basin at Mbakaou, Energy Environ. Res., 2, 2012.

Christopher, A. J. and Yung, C. A.: The use of HEC-HMS and HECGeoHMS to perform Grid-based Hydrologic Analysis of a watershed, ASFPM Conference, USA, 4 pp., 2001.

Chu, X. and Steinman, A. D.: Event and Continuous Hydrologic Modeling with HEC-HMS, J. Irrig. Drain. Eng.-ASCE, 135, 119-124, 2009.

Cunderlik, J. M. and Simonovic, S. P.: Hydrological extremes in a southwestern Ontario river basin under future climate conditions, Hydrolog. Sci. J., 50, 631-654, 2005.

De Laat, P. J. M.: Workshop on Hydrology, Lecture notes, UNESCO-IHE Institute for Water Education, Delft, the Netherlands, 2006.

De Laat, P. J. M. and Savenije, H. H. G.: Hydrology, Lecture notes, UNESCO-IHE Institute for Water Education, Delft, the Netherlands, 2002.

Du, J., Xie, S., Xu, Y., Chong-yu, X., and Vijay, P. S.: Development and testing of a simple physically-based distributed rainfallrunoff model for storm runoff simulation in humid forested basins, J. Hydrol., 336, 334-346, 2007.

FAO: Système d'information de la FAO sur l'eau et l'agriculture - Information system for water and agriculture, Food and Agriculture Organization (FAO) of the United Nation, Rome, Italy, 2005.

Fenicia, F., Savenije, H. H. G., Matgen, P., and Pfister, L.: Understanding catchment behavior through stepwise model concept improvement, Water Resour. Res., 44, W01402, doi:10.1029/2006WR005563, 2008a.

Fenicia, F., McDonnell, J. J., and Savenije, H. H. .: Learning from model improvement: On the contribution of complementary data to process understanding, Water Resour. Res., 44, W06419, doi:10.1029/2007WR006386, 2008b.

Fenicia, F., Wrede, S., Kavetski, D., Pfister, L., Hoffmann, L., Savenije, H. H. G., and McDonnell, J. J.: Impact of mixing assumptions on mean residence time estimation, Hydrol. Process., 24, 1730-1741, 2010.

Fenicia, F., Kavetski, D., and Savenije, H. H. G.: Elements of a flexible approach for conceptual modeling: Part 1. Motivation and theoretical development, Water Resour. Res., 47, W11510, doi:10.1029/2010WR010174, 2011.

HEC: Hydrologic Modeling System, HEC-HMS, User's Manual, Version 2.1, Hydrologic Engineering Center (HEC), US Army Corps of Engineering, Davis, CA, 2011.

Hoeg, S., Uhlenbrook, S., and Leibundgut, C.: Hydrograph separation in a mountainous catchment - combining hydrochemical and isotopic tracers, Hydrol. Process., 14, 1199-1216, 2000.

Fleming, M. and Neary, V.: Continuous Hydrologic Modeling Study with the Hydrologic Modeling System, J. Hydrol. Eng.-ASCE, 9, 175-183, 2004.

Gao, H., Hrachowitz, M., Fenicia, F., Gharari, S., and Savenije, H. H. G.: Testing the realism of a topography-driven model (FLEXTopo) in the nested catchments of the Upper Heihe, China, Hydrol. Earth Syst. Sci., 18, 1895-1915, doi:10.5194/hess-18-18952014, 2014.

Kashid, S. S., Ghosh, S., and Maity, R.: Streamflow Prediction using Multi-Site Rainfall Obtained from Hydroclimatic Teleconnection, J. Hydrol., 395, 23-38, 2010.

Klemes, V.: Operational testing of hydrological simulation models, Hydrolog. Sci. J., 31, 13-24, 1986.

Legates, D. R.: Evaluating the Use of 'Goodness of Fit' Measures in Hydrologic and Hydroclimatic Model Validation, Water Resour. Res., 35, 233-241, 1999.

McCuen, R. H., Knight, Z., and Cutter, A. G.: Evaluation of the Nash-Sutcliffe efficiency index, J. Hydrol. Eng., 11, 597-602, 2006.

Merwade, V.: Hydrologic Modeling using HEC-HMS, School of Civil Engineering, Purdue University, Purdue, USA, 2007.

Miao, C. Y., Duan, Q. Y., Sun, Q. H., and Li, J. D.: Evaluation and application of Bayesian Multi-model estimation in temperature simulations, Prog. Phys. Geogr., doi:10.1177/0309133313494961, in press, 2013.

Mul, M. L., Mutiibwa, K. R., Uhlenbrook, S., and Savenije, H. G. H.: Hydrograph separation using hydrochemical tracers in the Makanya catchment, Tanzania, Phys. Chem. Earth, 33, 151-156, 2008.

Munyaneza, O., Uhlenbrook, S., Wenninger, J., van den Berg, H., Bolt, H. R., Wali, G. U., and Maskey, S.: Setup of a Hydrological Instrumentation Network in a Meso-Scale Catchment - the case of the Migina Catchment, Southern Rwanda, Nile Water Sci. Eng. J., 3, 61-70, 2010.

Munyaneza, O., Ufiteyezu, F., Wali, U. G., and Uhlenbrook, S.: A simple Method to Predict River Flows in the Agricultural Migina Catchment in Rwanda, Nile Water Sci. Eng. J., 4, 24-36, 2011.

Munyaneza, O., Wenninger, J., and Uhlenbrook, S.: Identification of runoff generation processes using hydrometric and tracer methods in a meso-scale catchment in Rwanda, Hydrol. Earth Syst. Sci., 16, 1991-2004, doi:10.5194/hess-16-1991-2012, 2012a.

Munyaneza, O., Nizeyimana, G., Nsengimana, H., Uzayisenga, C., Uwimpuhwe, C., and Nduwayezu, J. B.: Surface Water Resources Assessment in the Rwasave Marshland, southern Rwanda, Nile Water Sci. Eng. J., 5, 58-70, 2012 b.

Nahayo, D., Wali, U. G., and Anyemedu, F. O. K.: Irrigation practices and water conservation opportunities in Migina marshlands, Int. J. Ecol. Develop., 16, 100-112, 2010.

Nash, J. E. and Sutcliffe, J. V.: River flow forecasting through conceptual models part I - A discussion of principles, J. Hydrol., 10, 282-290, 1970. 
Neary, V. S., Habib, E., and Fleming, M.: Hydrologic Modeling with NEXRAD Precipitation in Middle Tennessee, J. Hydrol. Eng.-ASCE, 9, 339-349, 2004.

O'Loughlin, G., Huber, W., and Chocat, B.: Rainfall-runoff processes and modelling, J. Hydraul. Res., 34, 733-751, 1996.

Oyebande, L.: Water problems in Africa-how can sciences help?, Hydrolog. Sci. J., 46, 947-961, 2001.

Pilgrim, D. H., Chapman, T. G., and Doran, D. G.: Problems of Rainfall-Runoff Modeling in Arid and Semiarid Regions, Hydrolog. Sci. J., 33, 379-400, 1988.

RNRA: Development of Rwanda National Water Resources Master Plan, Main report of Rwanda Natural Resources Authority, Ministry of Natural Resources, May 2013, Kigali, Rwanda, 2014.

Roy, D., Begam, S., Ghosh, S., and Jana, S.: Calibration and validation of HEC-HMS model for a river basin in Eastern India, ARPN J. Eng. Appl. Sci., 8, 847-864, 2013.

Ruelland, D., Ardoin-Bardin, S., Billen, G., and Servat, E.: Sensitivity of a lumped and semi-distributed hydrological model to several methods of rainfall interpolation on a large basin in West Africa, J. Hydrol., 361, 96-117, 2008.

Sardoii, E. R., Rostami, N., Sigaroudi, S. K., and Taheri, S.: Calibration of loss estimation methods in HEC-HMS for simulation of surface runoff (Case Study: Amirkabir Dam Watershed, Iran), Adv. Environ. Biol., 6, 343-348, 2012.

Savenije, H. H. G.: HESS Opinions "Topography driven conceptual modelling (FLEX-Topo)", Hydrol. Earth Syst. Sci., 14, 26812692, doi:10.5194/hess-14-2681-2010, 2010.

Schaefli, B. and Gupta, H. V.: Do Nash values have value?, Hydrol. Process., 21, 2075-2080, doi:10.1002/hyp.6825, 2007.

Scharffenberg, W. and Fleming, M.: Hydrologic modeling system HEC-HMS v3.2 user's manual, USACE-HEC, Davis, USA, 2010.

SHER: Etudes de faisabilite, Marais de la Migina. Rapport provisoire phase 2, Ministry of Agriculture, Kigali, Rwanda, 2003.

Snyder, F. F.: Synthetic unit hydrographs, Trans. Am. Geophys. Union, 19, 447-454, 1938.

Uhlenbrook, S. and Leibundgut, Ch.: Process-oriented catchment modeling and multiple response validation, Hydrol. Process., 16, 423-440, 2002.
Uhlenbrook, S., Seibert, J., Leibundgut, C., and Rodhe, A.: Prediction uncertainty of conceptual rainfall-runoff models caused by problems to identify model parameters and structure, Hydrolog. Sci. J., 44, 779-799, 1999.

UNEP: Connecting poverty and ecosystem services: A series of seven country scoping studies, focus on Rwanda, United Nations Environmental Programme (UNEP) and the International Institute for Sustainable Development (IISD), Nairobi, Kenya, 2005.

USACE: Technical Workshop on Watershed Modeling with HECHMS, US Army Corps of Engineers, California Water and Environmental Modeling Forum, Sacramento, California, 2008.

USACE-HEC: HEC-GeoHMS Geospatial Hydrologic Modeling Extension, v5.0, User's Manual, US Army Corps of Engineers, Hydrologic Engineering Center, University of Michigan, USA, October 2010.

USACE-HEC: Hydrologic Modeling System, HEC-HMS, v3.5, User's Manual, US Army Corps of Engineers, Hydrologic Engineering Center, Institute for Water Resources, University of California, Davis, CA, USA, August 2010.

Van den Berg, H. W. and Bolt, R. H. R.: Catchment analysis in the Migina marshlands, southern Rwanda, MSc thesis, Vriije University (VU) Amsterdam, Amsterdam, the Netherlands, p. 120, 2010.

Wenninger, J., Uhlenbrook, S., Lorentz, S., and Leibundgut, C.: Identification of runoff generation processes using combined hydrometric, tracer and geophysical methods in a headwater catchment in South Africa, J. Hydrolog. Sci., 53, 65-80, 2008.

Yawson, D. K., Kongo, V. M., and Kachroo, R. K.: Application of linear and nonlinear techniques in river flow forecasting in the Kilombero River basin, Tanzania, Hydrolog. Sci. J., 50, 783-796, 2005.

Yener, M. K., Şorman, A. Ü., Şorman, A. A., Şensoy, A., and Gezgin, T.: Modeling studies with HEC-HMS and runoff scenarios in Yuvacik basin, Turkey, Int. Congr. River Basin Manage., 4, 621-634, 2007. 